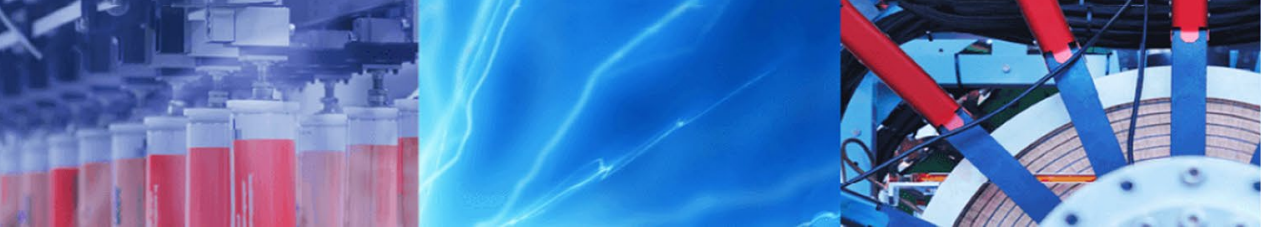

Research Article

\title{
Comparative study of bio-materials versus conventional materials in building construction methods; economical evaluation of different building materials
}

\author{
Abdelaziz F. Mohamed ${ }^{1}$. Mai Mokhtar ${ }^{2}$. Shaimaa Elghobashy ${ }^{2}$
}

C Springer Nature Switzerland AG 2019

\begin{abstract}
The problem of desertification has become a threat for many regions in Egypt as a result of climate change and the improper use of natural resources which has had a negative impact on human life and food shortages, leading to an increase in the migration rate. Many proposals have been presented to solve the problem of desertification but have not succeeded. Therefore, it was necessary to refer to nature and find solutions from it. Nature has been always a source of inspiration for human being in different aspects of their life, also it has been a part of human architecture since the early architectural periods in the caves that he used to live in and using materials from the surrounding nature, but this is not only what architecture took from nature it also influenced the form, function, space and structure. The aim of this research is to understand the role that nature plays in architecture to achieve buildings integrated with the surrounding environment with economical cost. It makes architects pay attention to nature as a source of inspiration in different perspectives. The case study of this paper presents the application of bio-material as a building and construction material and compares it with traditional building materials through the present worth method including the initial cost, characteristics and life time period to apply bio-material on a selected case study.
\end{abstract}

Keywords Desertification · Bio-materials · Feasibility study · Life cycle costing

\section{Introduction}

Each year the desert progresses $600 \mathrm{~m}[1]$, at a rate of $2 \mathrm{~m}$ per day, and in the Sahara alone arises Daily a billion new sand grains, needing new spaces and forcing people to migrate and more Poverty. The problem is very acute and it is standing in front of millions of people living on the borders of the desert in Africa (as shown in Fig. 1). One third of the land suffers from drought and $60 \%$ of the Earth's population is affected.

In 2003, twenty-three African States met to develop plans to combat desertification. The original plan was based on planting a million trees as a wall along the line of desertification that passes along the African continent. Certainly it was an initiative worthy of appreciation, but it faced many Practical difficulties not least that poor people were cutting trees to sell fuel [1].

As a result, most of the sciences start to look back to nature and inspire from it and many research and studies are done through this, the idea started from 1998 by Janine Benyus. Nowadays many researchers are working on it because they feel that nature is a great source to inspire from it. Jirapong believes that nature has many great lessons for human to study and learn from it. The creativity use of material, resourcefulness structural systems act in response to dissimilar kind of climatic and environmental forces. Tomasz and Rafal in their Structural design inspired by nature are saying "Complicated design problems needs novel solution to solve and as most of the solution already done in nature" [2].

\footnotetext{
$\triangle$ Abdelaziz F. Mohamed, drabdelaziz@aast.edu | ${ }^{1}$ Arab Academy for Science, Technology and Maritime Transport, Aswan, Egypt. ${ }^{2}$ Arab Academy for Science, Technology and Maritime Transport, Alexandria, Egypt.
}

SN Applied Sciences (2019) 1:1179| https://doi.org/10.1007/s42452-019-1218-5 


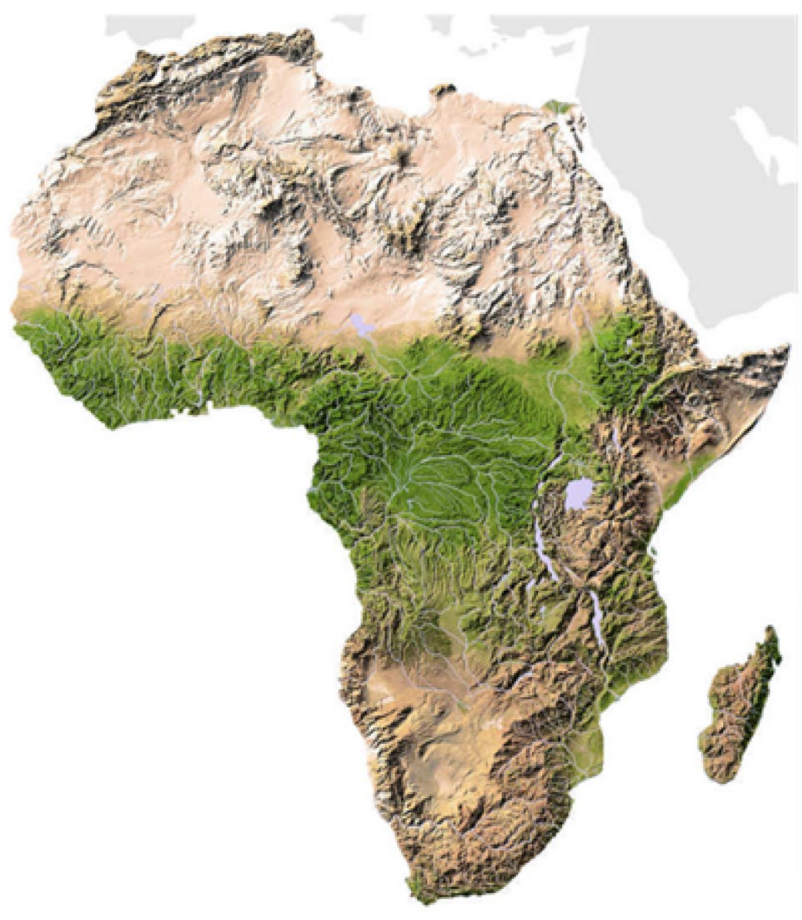

Fig. 1 The coverage of sand for five deserts in Africa. Source: sites. google.com

\section{Relationship between human and nature}

From the beginning of creation, human was surrounded by nature and influenced by it in its different design elements such as: form, function, space and structure. Everything in nature is well organized and in harmony [2]. It has been a source of inspiration for human in different aspects of their life and it can be a reflection of a person's beliefs and desires. Human is a part of the surrounding nature and the surrounding environment has an impact on human behaviors and attitude [3], the effect of the environment on behavior is direct, passive, simple and readily predictable $[4,5]$. The effects of the environment on human behavior are through responses of an emotional nature [6]. In fact human resort to nature for relaxation, refreshment and calmness due to the impact of its colors on human and giving the sense of inner happiness [7].

Nature is an emotional element within the surrounding environment and is an important aspect to deal with everyday affecting everything around human. Human always communicates with nature; since starting to build shelters and using them, nature has been used as an important and basic part in the plans and designs. Human being noticed the advantages of communicating with nature as; health, less stress and sickness. Plants

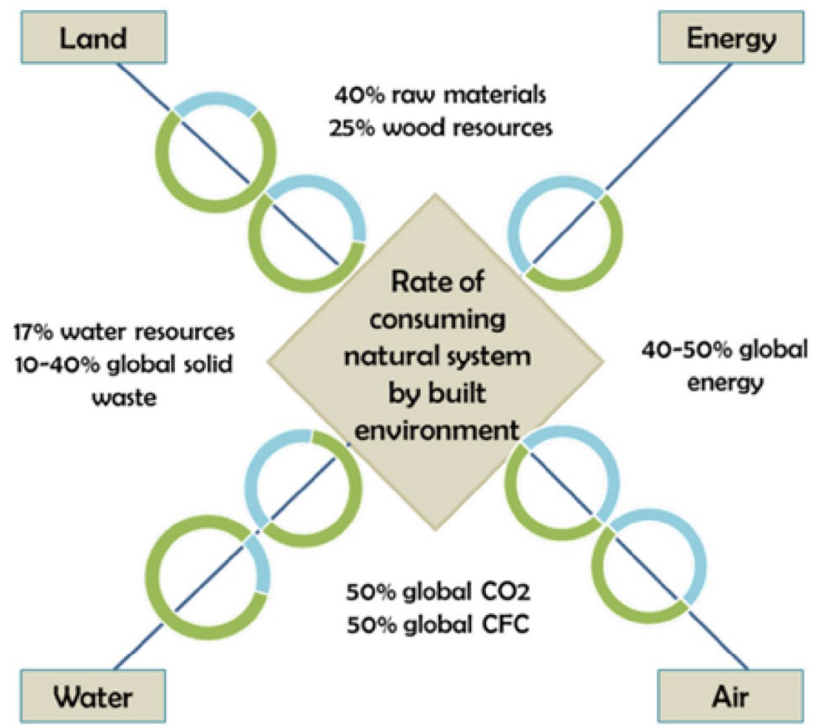

Fig. 2 Nowadays built environment and the energy it consumes (Researcher)

and green spaces can help in perfection and safety in the cities and improvement of social relationship and interaction in residential environments [8].

By time passing and in the presence of technology development respect to nature decreased and human became over nature, replacing technology as a metaphor instead of nature as a metaphor results in a major difference in the relationship between human, architecture and nature. Most of nowadays designs and its application harm the natural environmental system that supports human lives on planet and convert the green planet into a concrete one as human architecture is the largest consumer for natural resources (as shown in Fig. 2), which result in lack of buildings integrated with the surrounding environment and neglecting natural elements during the design process, lack of natural interior spaces although it helps in solving environmental problems facing earth by minimizing the energy usage, water and raw materials. Therefore, one of the design solutions for architects and designers to increase the optimization in their design works is looking at nature in every aspect deeper and try to apply it on the conceptual design [4].

\section{Importance of designing with nature}

It creates new architecture integrated with the environment to achieve human needs and satisfaction. New natural ideas are capable of creating new understanding and therefore, new realities. It approaches building forms to the elements in nature to be familiar for human being. It is an important and effective tool for creativity and it gives 


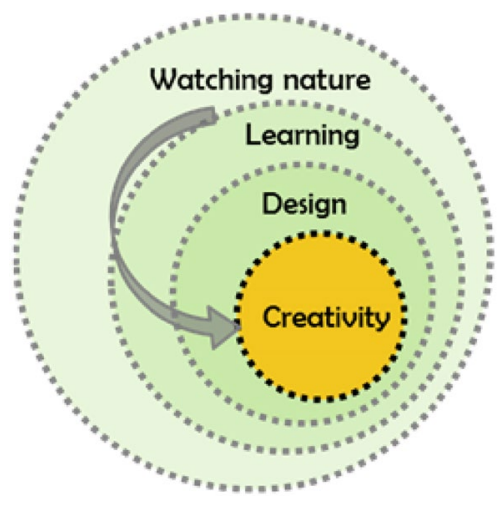

Fig. 3 Designing form nature is the source of creativity (Researcher)

the ability for designers to express their own ideas and find several design solutions [3] (as shown in Fig. 3).

\section{Construction from nature in desert environment}

Bacillus pasteurii is a friendly type of bacteria that has been used lately as a construction method in different projects to save the land from desertification [5] (as shown in Fig. 4).

\subsection{Sand dune project by Magnus Larsson}

The architect Magnus Larsson began to think in a way to solve the problem of desertification with architecture. The idea was to move buildings next to the trees, and then people could live under the shadow of the trees, at the same time the need to stabilize the sand movement. The idea was to use materials available in the area; the sand itself without the need for transport or purchase (as shown in Fig. 5) $[9,10]$.

Through the sand-stuffing can build a wall along $6000 \mathrm{~km}$ to be a green belt. The problem faced the idea was how to convert sand into stones? After a period of research and testing Magnus arrived That bacteria Bacillus pasteurii can do the job at the cheapest prices and most efficient and a long life time which is more than 100 years (as shown in Figs. 6, 7) $[9,10]$.

A particular microorganism, Bacillus pasteurii, is flushed through the dun-escape, which causes a biological reaction that turns the sand into solid sandstone. The initial reactions finish within $24 \mathrm{~h}$; it would take about a week to saturate the sand enough to make the structure habitable. The bacteria are non-pathogenic and die in the process of solidifying the sand, also the wind could change the form by solidifying parts of the surface to force the grains of sand to align in certain patterns, certain shapes, having the

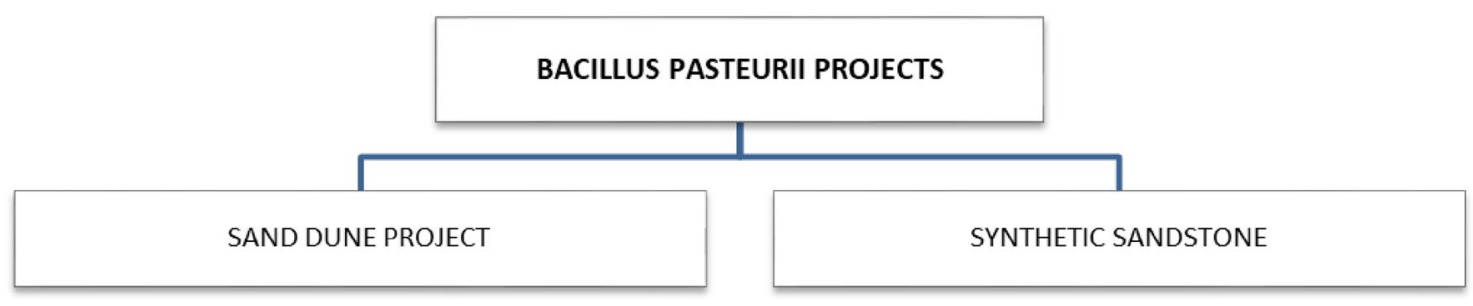

Fig. 4 Proposed projects saving land from desertification (Researcher)
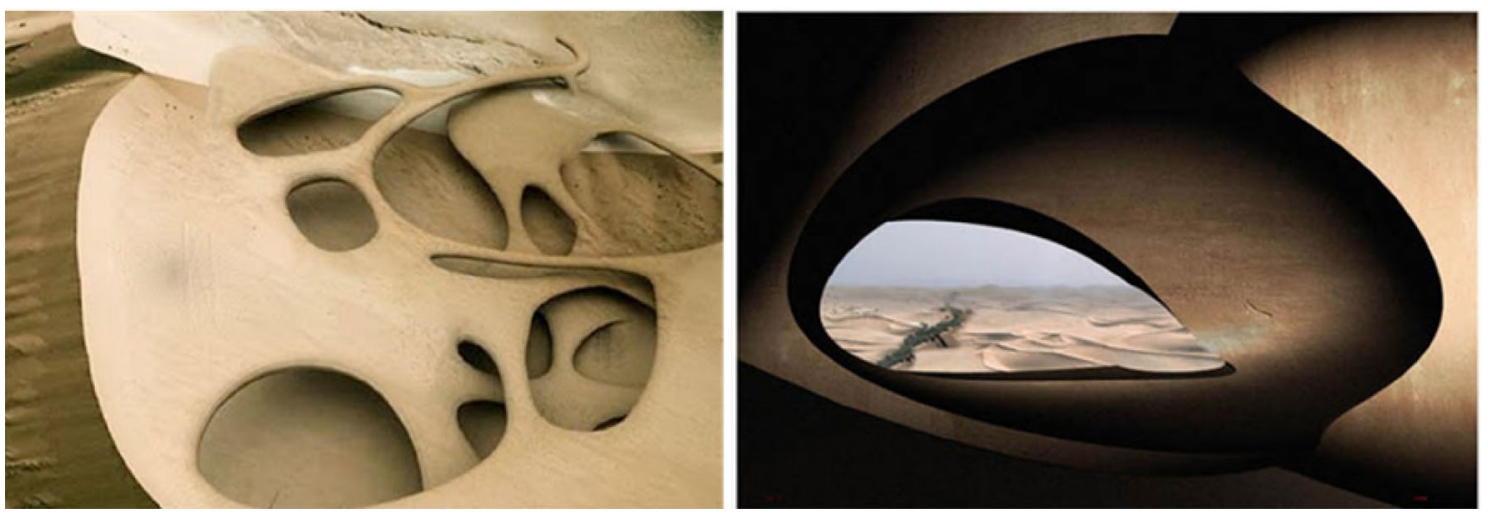

Fig. 5 The Dune project design. Source: bldgblog.com 

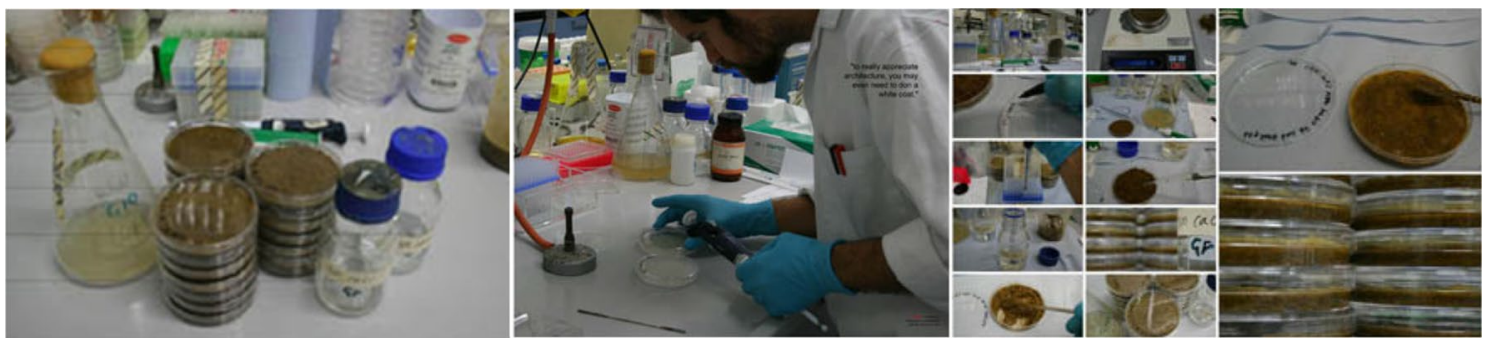

Fig. 6 Testing the Bacillus pasteurii bacteria. Source: bldgblog.com

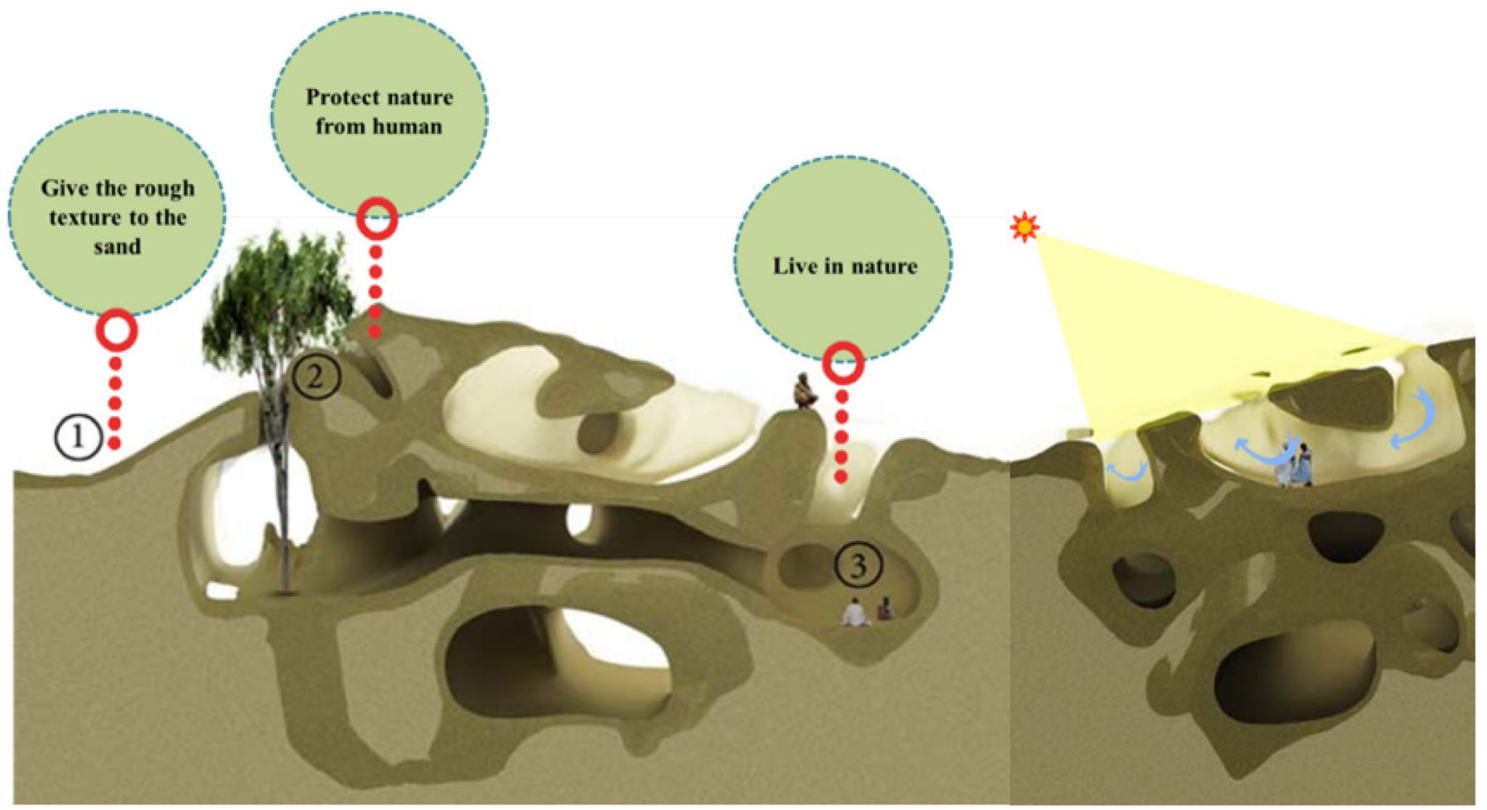

Fig. 7 The benefits for the solidified sand structure. Source: bldgblog.com

wind blow out our voids, creating a structure that would change and change again over the course of a decade, a century, a millennium (as shown in Fig. 8) [11, 12].

\section{Construction methods}

- A balloon-like pneumatic structure filled with Bacillus pasteurii, which would then be released into the sand and allowed to solidify the same into permaculture architecture (as shown in Fig. 9) [9].

- The piles would be pushed through the dune surface and a first layer of bacteria spread out, solidifying an initial surface within the dune. They would then be pulled up, creating almost any conceivable (structurally sound) surface along their way, with the loose sand acting as a jig before being excavated to create the necessary voids (as shown in Fig. 10) [9].
The architectural form is derived from tafoni, a cavernous rock structure that formally ties the project back to notions of aggregation and erosion (as shown in Fig. 11). These forms are porous and have a large surface area which will help in inner ventilation and relaxing temperature, for bacteria in the soil, you can get infinity of artistic formations that match the surrounding environment [11, $12]$.

The temperature difference between the interior and the exterior of the solidified dunes makes it possible to create nodal points that could both support water harvesting and inhabitable thermal comfort zones. This gives the chance for growing oases in the desert, and stops the sand from pushing people away from their homes and villages (as shown in Fig. 12) [11, 12].

The design mainly depends on curves and organic lines which add beauty to the design and it respects the human scale and proportion within the interior space (as shown in Fig. 13) [11, 12]. 

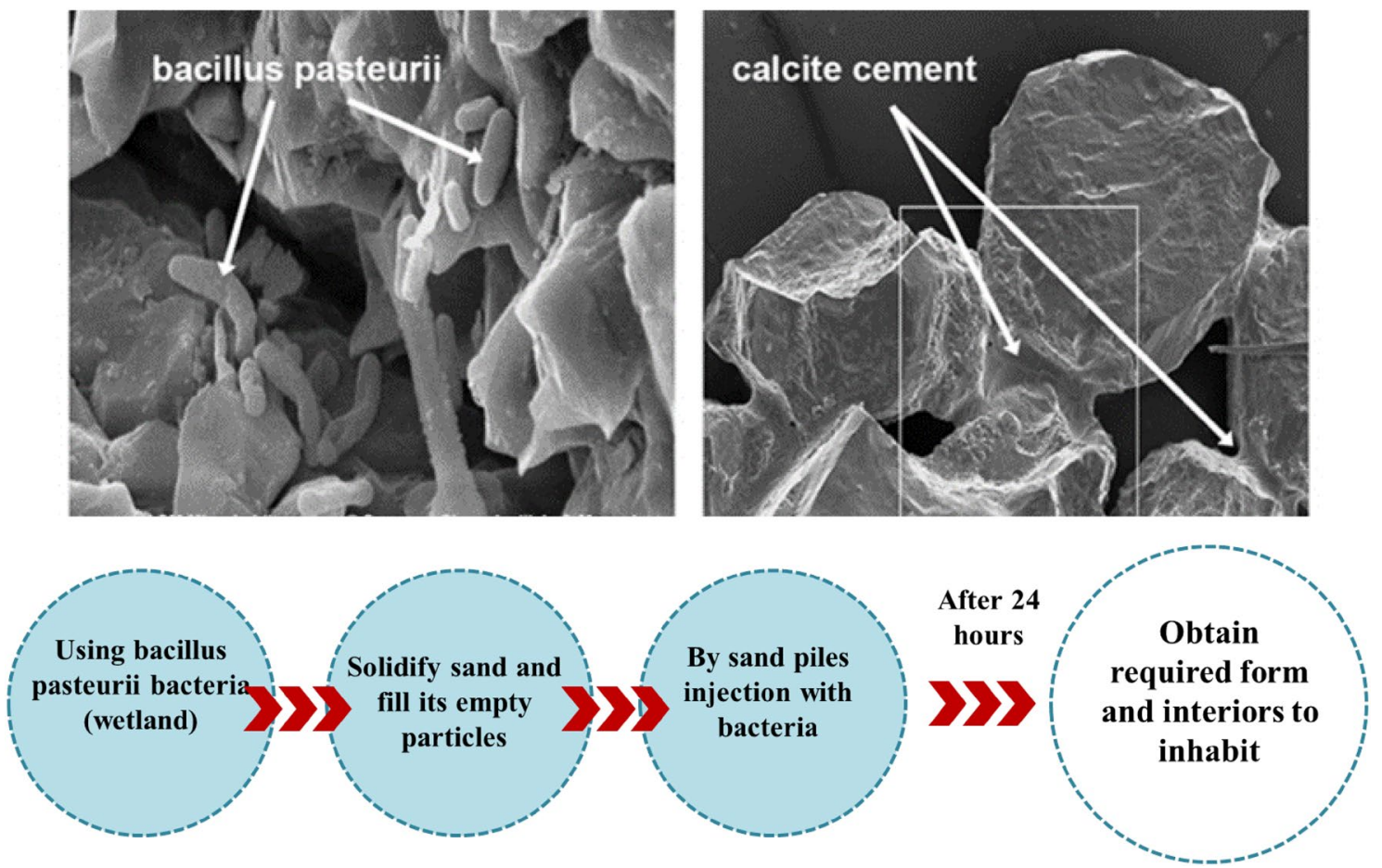

Fig. 8 Steps for obtaining Bacillus pasteurii structure. Source: bldgblog.com and Authors

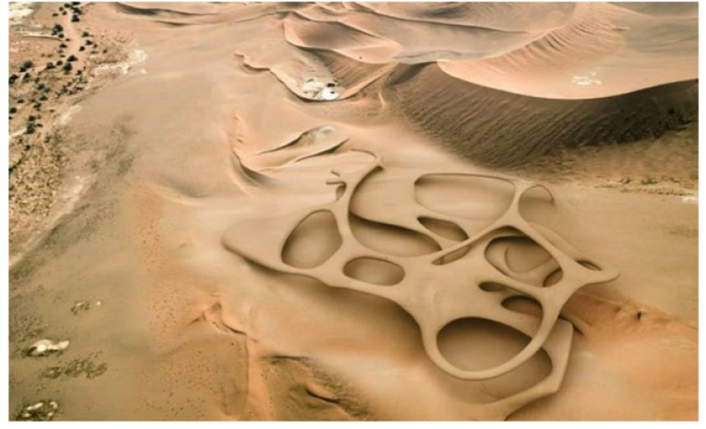

Fig. 9 Structure created by balloon. Source: bldgblog.com

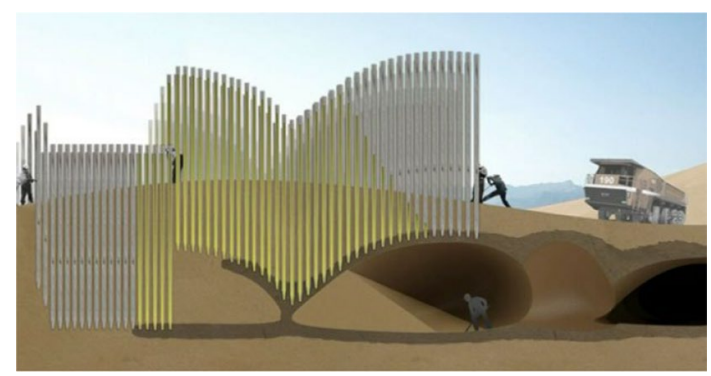

Fig. 10 Structure created by sand injection. Source: bldgblog.com
Researchers at the University of California at Davis have been investigating the technique which involves injecting the bacterium Bacillus pasteurii into the soil in a calciumrich, alkaline mix as a means to stabilize the ground in earthquake-prone regions. In the lab, it can solidify 32 square feet of soil in a matter of hours, although they estimate that it would take up to a few weeks for large-scale solidification [13].

\subsection{Synthetic sandstone bricks}

Professor Ginger Dosier invented a way of constructed sand bricks with the help of bacteria; the bacteria that munch on natural crude oil in ocean water or in sand; take the wondrous critter, Bacillus pasteurii that can turn sand into sandstone and heal cracks in concrete. The architect chose the bricks as they are so humble and are the lowest common denominator in architecture. The sand brick differs than the standard brick which result in more atmospheric pollution and consumes large amounts of energy, as it must be fired in a kiln at temperatures greater than 1000 degrees centigrade; making a couple of bricks generates more than a kilogram of carbon dioxide and it's estimated that perhaps 1.2 trillion bricks are manufactured around the world every year. The bacteria treated the bricks easily as it produces calcite that can glue sand grains together, treating the bacteria right requires feeding them 

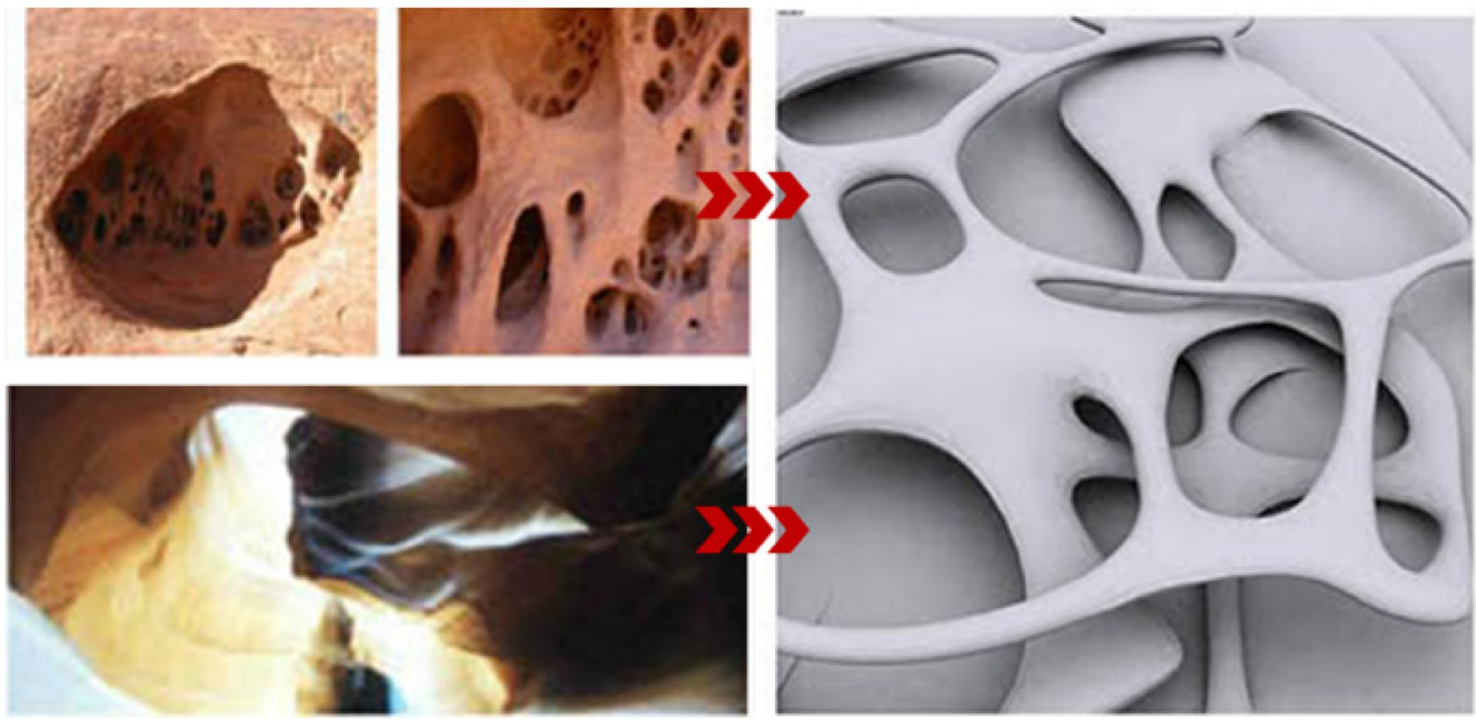

Fig. 11 The concept of architectural form of Bacillus pasteurii structure. Source: bldgblog.com
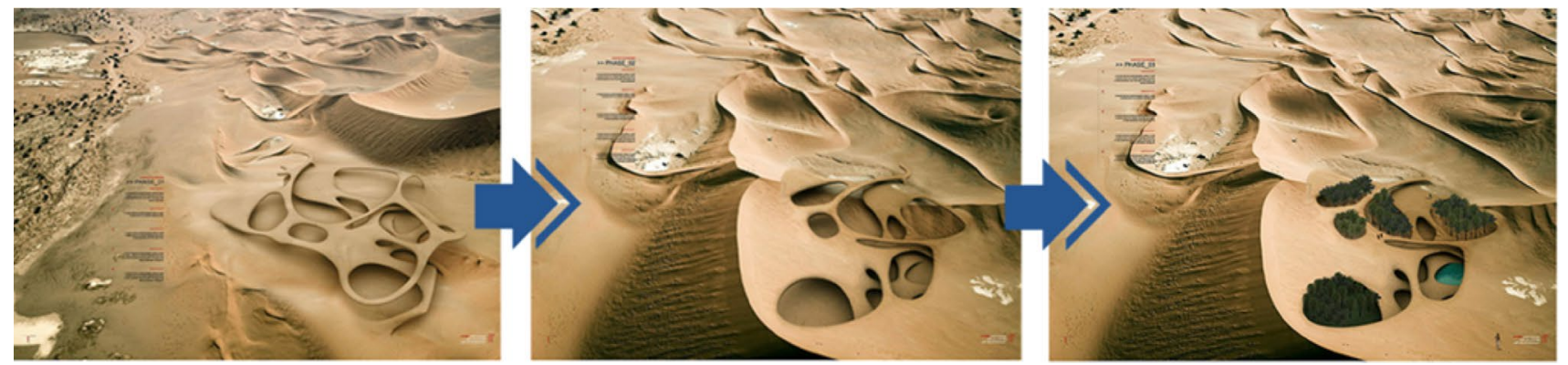

Fig. 12 Phases of form transformation of the sand dune project. Source: bldgblog.com

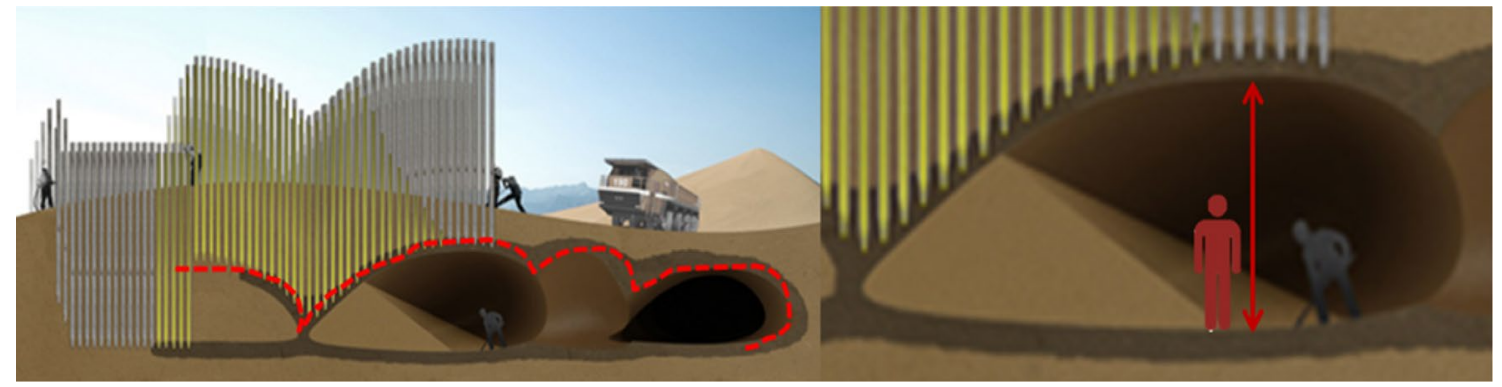

Fig. 13 Curvy interiors respecting human scale and proportion. Source: bldgblog.com

which is where the urine comes in, can be made synthetically or from urine, and provides nutrition for the bacteria. Water is also necessary, as is calcium chloride (as shown in Fig. 14) [14].

The process for making a brick is relatively straightforward: by putting dry sand into a mold, adding the cultured bacteria, water, urea, and calcium chloride, and the process takes about a week under 37 degrees centigrade at which the bacteria must be prepared and no heating is required. The brick is about $3 \mathrm{~cm}$ long, $1.5 \mathrm{~cm}$ wide and a centimeter deep (as shown in Fig. 15) [14]. 


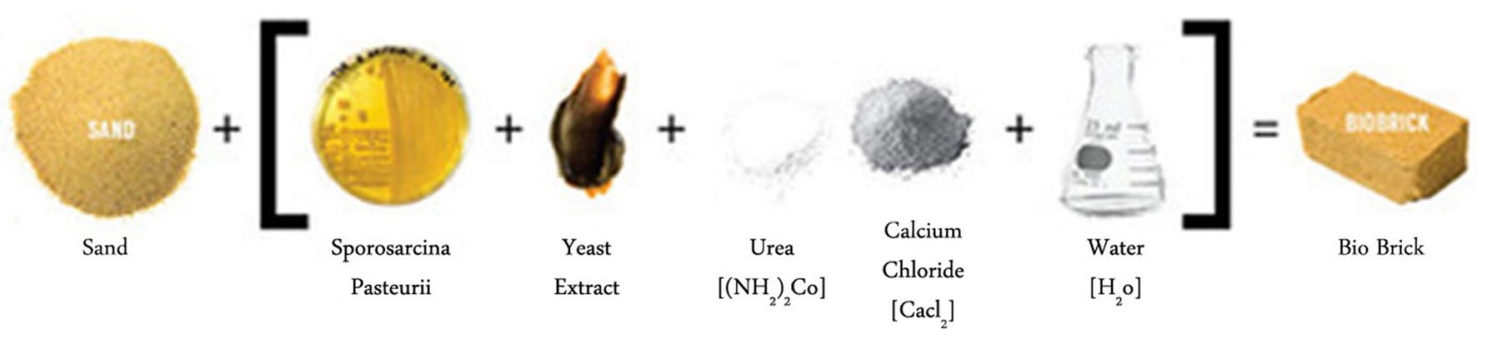

Fig. 14 The components of sand bricks. Source: throughthesandglass.typepad.com
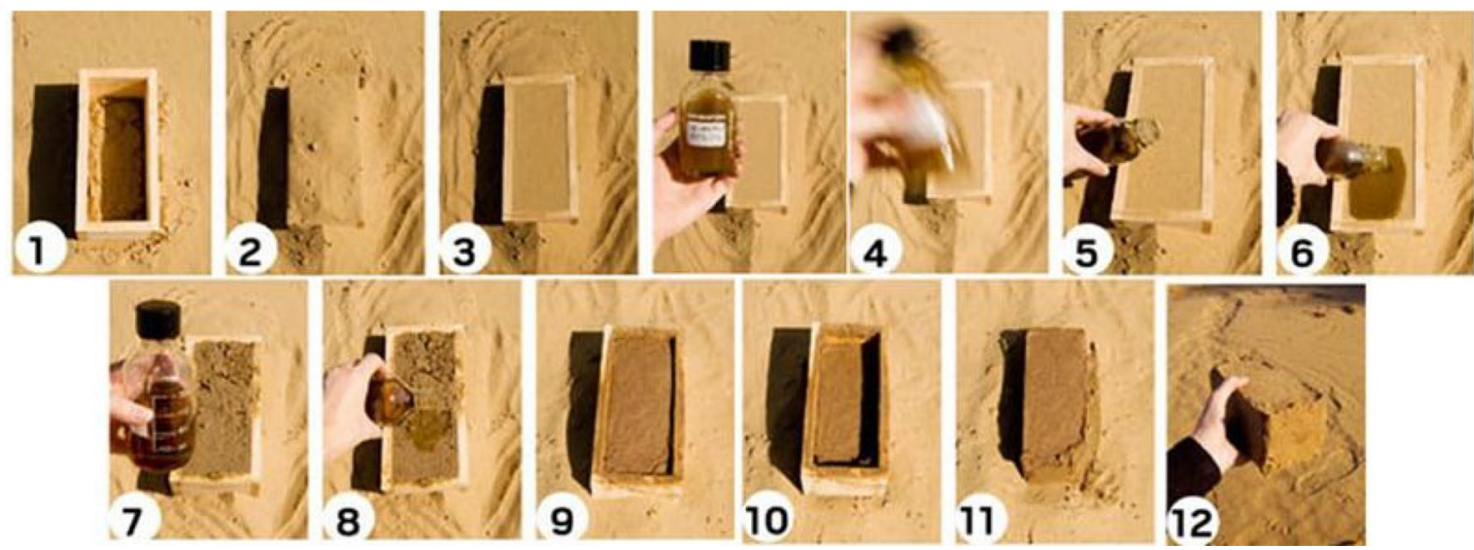

Fig. 15 Stages for creating sand bricks. Source: throughthesandglass.typepad.com

\subsection{Bacillus pasteurii material cost}

The initial price for the purchase of bacteria is $\$ 60$, which is the price that won't be paid again, the cubic meter of bacterial dirt costs about $\$ 11$, which is considered a low cost compared to reinforced concrete that costs about $90 \$$ [12].

\section{Case study}

This research hypothesizes that forms and materials inspired from nature are the most feasible for different architectural projects. The selected site is a residential project in Borg el-Arab District in Alexandria (as shown in Fig. 16). The site is located in the desert of King Maryout and the main view is the Maryout Lake with dimensions $22 \mathrm{~m} * 30 \mathrm{~m}$. The local materials are white stones and sand. A natural structure will be tested using bacteria material using 3D max for the structure and simulation for sunlight in the desert environment of Alexandria, Egypt (as shown in Fig. 17).

The form of the structure is derived from living organisms bone structure as it contributes with different environments due to their existence in all environments. The structure is porous to allow light and ventilation for the interior spaces (as shown in Fig. 18).

A direct comparison between the organic form and regular form was formed to obtain the amount of light and temperature for each (as shown in Fig. 19).

The temperature differs and the light control in case of organic is better than regular form which proves that organic forms create better living spaces for human being than regular forms (as shown in Fig. 20).

A direct comparison between construction materials is done in desert environment.

\subsection{Bacillus pasteurii bacteria}

Cost is a key constraint of the project, a budget for the current project is included in this paper and the Bacillus pasteurii bacteria was chosen to be tested. The initial price of a new residential villa using the Bacillus pasteurii bacteria is estimated at $\$ 7260$. This cost includes material and labor costs. The material will be compared with two other materials which are reinforced concrete and rammed earth to be applied on the same residential project (as shown in Table 1). 


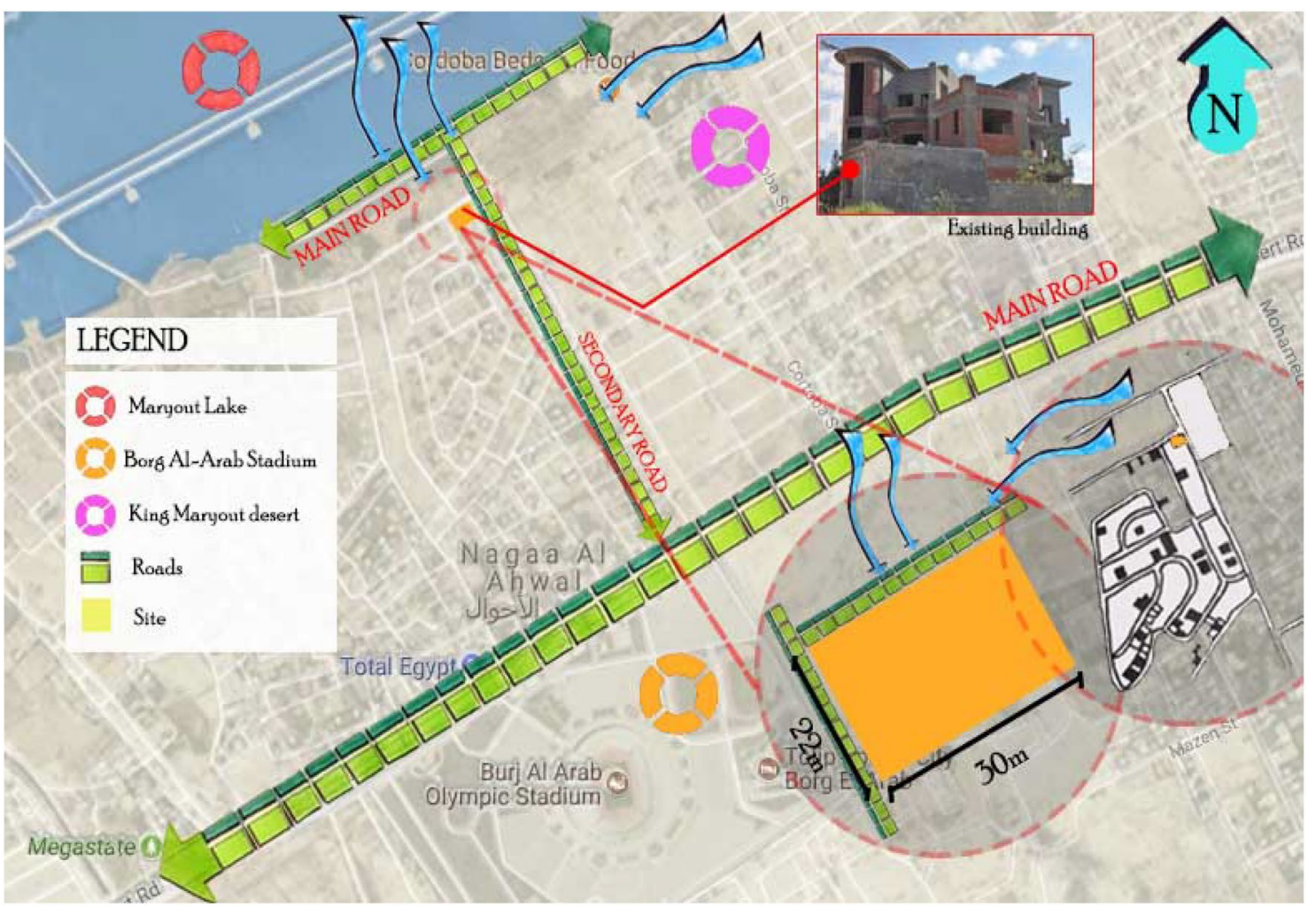

Fig. 16 Selected site analysis. Source: Authors; googlemaps.com

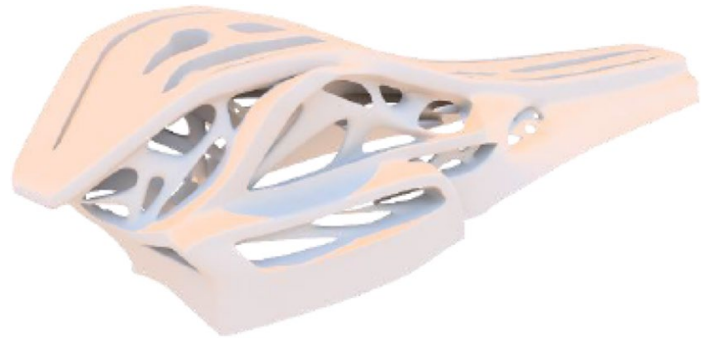

Fig. 17 3d shot for the structure. Source: Researcher

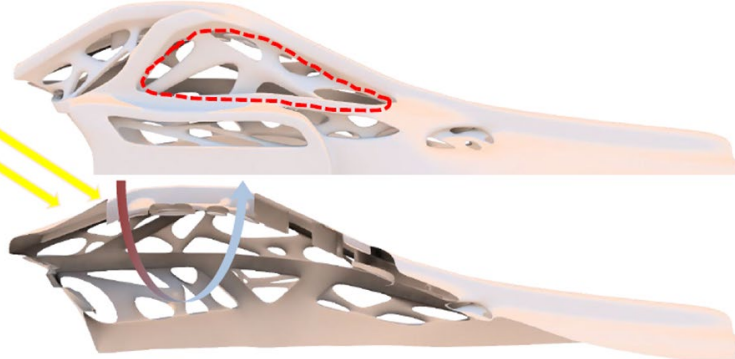

Fig. 18 Porous form for the unit. Source: Researcher

\subsection{Reinforced concrete}

Concrete in which steel is embedded in such a manner that the two materials act together in resisting forces. The reinforcing steel rods, bars, or mesh absorbs the tensile, shear, and sometimes the compressive stresses in a concrete structure. Plain concrete does not easily withstand tensile and shear stresses caused by wind, earthquakes, vibrations, and other forces and are therefore unsuitable in most structural applications. In reinforced concrete, the tensile strength of steel and the compressive strength of concrete work together to allow the member to sustain these stresses over considerable spans. The invention of reinforced concrete in the nineteenth century revolutionized the construction industry, and concrete became one of the world's most common building materials.

Cost: $\$ 70$ per cubic meter [15].

\subsection{Rammed earth}

Rammed earth construction is an ancient method originating in Africa, it is best if locally sourced earth is used 
Fig. 19 Organic form and regular form in desert environment. Source: Researcher
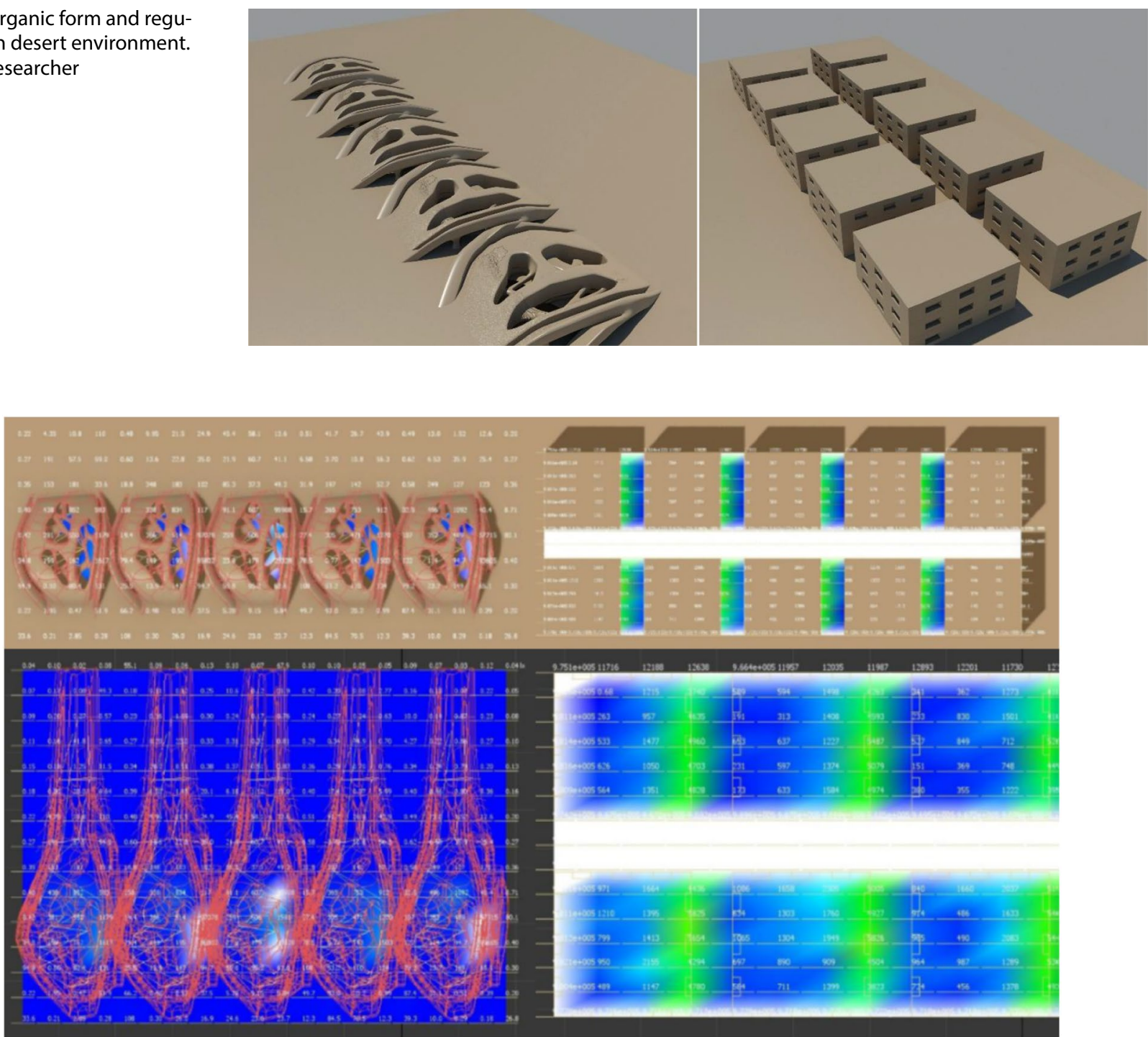

Fig. 20 The amount of ultra violet sunrays is very low in case of bacteria material (less 7 times than regular) and all the spaces are well lit. Source: Researcher

Table 1 Initial cost for the three selected materials. Source: Authors

\begin{tabular}{|c|c|c|c|}
\hline Material & Reinforced concrete & Solidified sand & Rammed earth \\
\hline Components & $\begin{array}{l}\text { Reinforced concrete-plain } \\
\text { concrete-bricks-finishing }\end{array}$ & Sand-bacteria & $\begin{array}{l}\text { Steel-timber-concrete- } \\
\text { precast concrete-brick- } \\
\text { earth }\end{array}$ \\
\hline Building life time & 50 years & More than 100 years & More than 100 years \\
\hline Area & $22 * 30=660 \mathrm{~m}^{2}$ (3 floors) & & \\
\hline Total initial cost & $435,712 \$$ & $21,780 \$$ & $495,000 \$$ \\
\hline
\end{tabular}

rather than transported to site, which will lower the walls embodied energy. Forms are made from wood and filled with combination of different earths and a concrete a couple inches at a time and is tamped in layers. The large thermal mass is good for regulating indoor temperature thus reducing heating and cooling 
Table 2 Comparison between three alternatives characteristics. Source: Authors

\begin{tabular}{|c|c|c|}
\hline Type & Advantages & Disadvantages \\
\hline Reinforced concrete & $\begin{array}{l}\text { Traditional method of construction } \\
\text { Using local materials }\end{array}$ & $\begin{array}{l}\text { High cost } \\
\text { Short life time } \\
\text { Not environmentally friendly } \\
\text { No creativity in form }\end{array}$ \\
\hline Bacteria & $\begin{array}{l}\text { Low cost } \\
\text { Long life time } \\
\text { Creates any type of form } \\
\text { Using native materials }\end{array}$ & $\begin{array}{l}\text { Part of the building is underground } \\
\text { Bacteria is not a native material (needs to be imported) }\end{array}$ \\
\hline Rammed earth & $\begin{array}{l}\text { Long life time } \\
\text { Environmentally friendly }\end{array}$ & $\begin{array}{l}\text { High cost } \\
\text { The structure requires lots of materials to construct it } \\
\text { No creativity in form }\end{array}$ \\
\hline
\end{tabular}

Table 3 Comparison between three alternatives cost. Source: Authors

\begin{tabular}{|c|c|c|c|c|c|c|}
\hline \multirow[t]{2}{*}{ Item } & \multicolumn{2}{|l|}{ Alternative 1} & \multicolumn{2}{|l|}{ Alternative 2} & \multicolumn{2}{|l|}{ Alternative 3} \\
\hline & Original & P.W & Original & P.W & Original & P.W \\
\hline \multicolumn{7}{|l|}{ Initial cost } \\
\hline Initial cost $(\$)$ & 435,712 & 435,712 & 21,780 & 21,780 & 495,000 & 495,000 \\
\hline Design cost & $5 \%$ & 21,780 & $10 \%$ & 2178 & $7 \%$ & 34,650 \\
\hline License cost & $1 \%$ & 4357 & $1 \%$ & 217.8 & $1 \%$ & 4950 \\
\hline Initial cost & & $461,854.57$ & & $24,175.8$ & & 534,600 \\
\hline Useful life & 50 years, $I=10 \%$ & & 100 years, $I=10 \%$ & & 100 years, $I=10 \%$ & \\
\hline \multicolumn{7}{|l|}{ Replacement } \\
\hline PW of replacement cost & 3955 & $\mathrm{P} 1=1525$ & 2825 & $\mathrm{P} 1=1089$ & 5650 & $P 1=2178$ \\
\hline$P 110$ years, $P / F, I, n$ & & $P 2=588$ & & $P 2=420$ & & $P 2=840$ \\
\hline P2 20 years, & & P3 $=277$ & & $P 3=162$ & & $P 3=324$ \\
\hline P3 30 years, & & $P 4=87$ & & $P 4=62$ & & $P 4=125$ \\
\hline P4 40 years, & & $\mathrm{P} 5=34$ & & P5 $=24$ & & $\mathrm{P} 5=48$ \\
\hline P5 50 years, & & & & $P 6=165$ & & $P 6=19$ \\
\hline P6 60 years, & & & & $\mathrm{P} 7=9$ & & $\mathrm{P} 7=7$ \\
\hline P7 70 years, & & & & $P 8=1.4$ & & $P 8=3$ \\
\hline P8 80 years, & & & & $P 9=0.5$ & & $P 9=1$ \\
\hline P8 90 years, & & & & $P 10=0.3$ & & $P 10=0.6$ \\
\hline \multicolumn{7}{|l|}{ P8 100 years, } \\
\hline Total PW replacement cost & & $2460 \$$ & & $1772 \$$ & & $3544 \$$ \\
\hline \multicolumn{7}{|l|}{ Salvage } \\
\hline Salvage cost (20\%) & 87,142 & $741 \$$ & 4356 & $0.4 \$$ & 99,000 & $9.9 \$$ \\
\hline \multicolumn{7}{|l|}{ Annual } \\
\hline Pw of maintenance cost (1\%) & 77,121 & $43,200 \$$ & 2178 & $21,778 \$$ & 4950 & $49,497 \$$ \\
\hline Present worth & $895,644 \$$ & & $28,126 \$$ & & $587,631 \$$ & \\
\hline \multicolumn{7}{|c|}{ The owner should select the proposal no. 2 , because it is the economical one } \\
\hline
\end{tabular}

The salvage value is the assumed value of the three alternatives after the useful life and the maintenance (annual cost) cost of the three alternatives

bills, and with slight modification this method can be used in any climate.

Cost: $\$ 250$ per vertical square meter of wall at $30 "$ thick [16].
A direct comparison for the advantages and disadvantages for the three materials is required to help select the best alternative as shown in Table 2: 


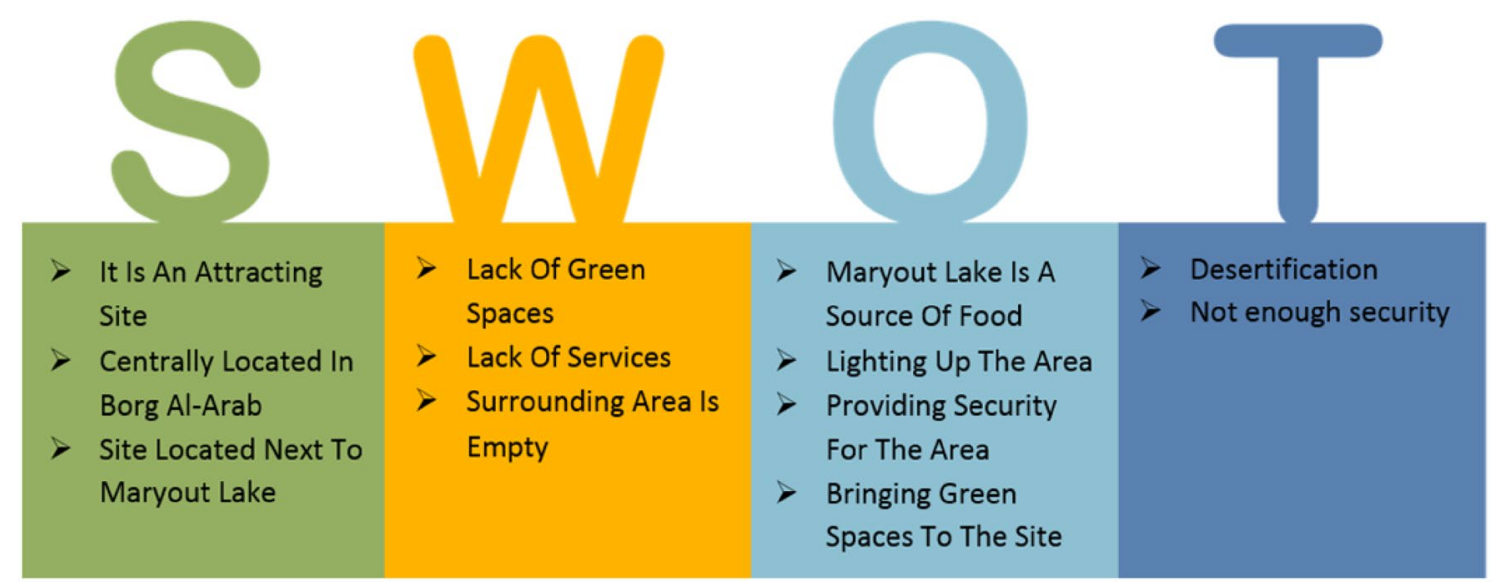

Fig. 21 SWOT analysis for the selected site. Source: Authors

Alternative No. 1 is Reinforced Concrete

Alternative No. 2 is Bacillus pasteurii bacteria

Alternative No. 3 is Rammed earth

Feasibility study between the three materials is done to select the best economical material for the project as shown in Table 3.

The proposed material alternative is the solidified bacterial sand as it achieves the best economical material from the other two alternatives.

\section{Results}

A comparison between three different materials was done through a feasibility study using the present worth method. The three material in the process were as following:

The first alternative was the reinforced concrete, while the second alternative was Bacillus pasteurii material, and the third one was the rammed earth. The initial cost of each material was calculated according to the following aspects: cost of the material per meter square multiplied by the total area of the building, design cost of the architect, and the building license cost.

The design cost of the three alternatives were: $5 \%, 10 \%$, and $7 \%$ respectively. It was obvious that the design cot of the Bacillus pasteurii was doubled the percentage of the reinforced concrete material due to the creativity and innovative design required for the design. The total initial cost demonstrated that the third alternative (rammed earth) was the highest in cost at 534,600\$, while the second alternative (Bacillus pasteurii) indicated the lowest cost at $24,175.8 \$$.

After that the replacement cost was figured according to the useful life of each material. Both Bacillus pasteurii and rammed earth had the longest useful life, each was considered at 100 years. The results showed that the total present worth replacement cost of the reinforced concrete material and rammed earth were inflated in cost at 2460 $\$$ and 3544 \$ respectively. On the other hand, the Bacillus pasteurii demonstrated much lower cost than the other alternatives at $1772 \$$. The maintenance cost also was considered at $1 \%$ of the initial cost for each alternative. Moreover, the salvage was deducted from the total present worth at $20 \%$ for each material.

Finally, the total present worth was deliberated for the three alternatives. The rammed earth material scored the highest cost among the other alternatives, which equaled $587,631 \$$. While the other two materials cost were as following: Reinforced concrete $895,644 \$$, and Bacillus pasteurii 28,126 \$. Therefore, it was concluded that the second alternative was the most economical choice. After analyzing the economic feasibility of bacterial material to other materials a SWOT analysis for the selected site was carried out (as shown in Fig. 21) to help take the future decision.

\section{Conclusions}

Bio-material is able to compete the traditional materials in construction industry. The proposed material is more effective, economic than the traditional materials on the long run.

A feasibility study was carried out using the present worth method. Three alternative materials was applied for comparison. Based on the information presented in the pre-mentioned feasibility study done to choose the best material to be applied at the residential villa of Borg Al Arab. It is recommended that the owner should select 
the second proposal (Bacillus pasteurii material) because it is the most economical one.

The findings of the feasibility study show that this initiative will be highly beneficial to the organization and has a high probability of success. Key findings are as follows: The second option got the lowest initial cost, also the total PW of replacement cost is the lowest for the second alternative. Moreover, the second option got the lowest salvage cost, which means it got the lowest total amount of depreciation expense, and the present worth cost of maintenance was the modest among the three alternatives.

\section{Compliance with ethical standards}

Conflict of interest The authors declare that they have no conflict of interest.

\section{References}

1. Manaugh G (2009). https://www.bldgblog.com/2009/04/sands tone/. Accessed 26 Nov 2017

2. Vahedi A (2009) Nature as a source of inspiration of architectural conceptual design. Master of Science in Architecture, Eastern Mediterranean University

3. Madden TJ, Hewett K, Roth MS (2000) Managing images in different cultures: a cross-national study of color meanings and preferences. J Int Mark 8(4):90-107

4. Cronbach L (1975) Beyond the two disciplines of scientific psychology. J Am Psychol 30:116-128

5. Proshansky HM, Ittelson WH, Rivlin LC (1970) Environmental psychology: man and his physical setting. Holt, Rinehart and Winston, New York

6. Festinger L, Schacter S, Back K (1950) Social pressure in informal groups. Halper, New York
7. Al-Soliman TM (1990) The impact of the surrounding environment on people's perception of major urban environmental attributes. J King Saud Univ 2:43-60

8. Panahi S, Mirzaei Q, Mohammadikia M (2013) Comparative analysis of natural elements in the architecture of Tabriz and Kashan Houses. Middle East J Sci Res 13:507-517

9. Shea C (2009). http://archive.boston.com/bostonglobe/ideas/ brainiac/2009/04/growing_a_wall.html/. Accessed 26 Nov 2017

10. Brassfield M (2009) https://www.trendhunter.com/trends/susta inable-dunescapes-magnus-larsson-plans-to-re-landscape-thesahara/. Accessed Nov 2017

11. Islamic Arts Magazine (2011) https://islamicartsmagazine.com/ magazine/view/sahara_surreal_-_magnus_larsson/. Accessed 26 Nov 2017

12. Architecture and construction builders (2011) https://www. bonah.org/. Accessed Mar 2018

13. Bradley J (2010) https://www.popsci.com/technology/artic le/2010-06/environmental-visionaries-sand-sculptor. Accessed 30 Apr 2018

14. Belford N (2010) https://throughthesandglass.typepad.com/ through_the_sandglass/2010/07/sandbacteriaurinebricks-conti nuing-performances-of-bacillus-pasteurii.html. Accessed $30 \mathrm{Apr}$ 2018

15. The Editors of Encyclopedia Britannica (2014) https://www.brita nnica.com/technology/reinforced-concrete/. Accessed Nov 2017

16. Magwood C (2017) Rammed earth construction basics. https ://endeavourcentre.org/2017/01/rammed-earth-construction/. Accessed Feb 2019

Publisher's Note Springer Nature remains neutral with regard to jurisdictional claims in published maps and institutional affiliations. 